\title{
Concerning the cohabitation of animals and algae - an English translation of K. Brandt's 1881 presentation "Ueber das Zusammenleben von Thieren und Algen"
}

\author{
Thomas Krueger $^{1}$ (D)
}

Received: 19 April 2016 / Accepted: 7 July 2016

(C) Springer Science+Business Media Dordrecht 2016

\begin{abstract}
Keywords Symbiosis · Cnidaria $\cdot$ Zoochlorella Zooxanthella $\cdot$ Coral Reefs $\cdot$ Hydra
\end{abstract}

\section{Introduction}

"This investigation shows that self-formed chlorophyll is absent in animals. If chlorophyll can be found in animals, it is due to invading plants that have kept their morphological and physiological independence". This conclusion, published by the German botanist Karl Andreas Heinrich Brandt (1854 1931 ) in 1881, represents the final quintessence of a number of ideas and experimental findings in the field of symbiosis research at that time. Karl Brandt, corroborating and adding to the work of others, determined through observational and experimental evidence that the green and yellow cells in some marine and freshwater animals were indeed independent organisms that live together with their host.

One of the fundamental topics of endosymbiotic research in the second half of the nineteenth century concerned the presence of green pigment in animals. This simple observation sparked two related and far-reaching questions: (1) Does this colouration indicate the presence of plant chlorophyll? And if

Electronic supplementary material The online version of this article (doi:10.1007/s13199-016-0439-2) contains supplementary material, which is available to authorized users.

Thomas Krueger

thomas.krueger@epfl.ch

1 Laboratory for Biological Geochemistry, School of Architecture, Civil and Environmental Engineering (ENAC), École Polytechnique Fédérale de Lausanne (EPFL), 1015 Lausanne, Switzerland so, (2) is this chlorophyll of endogenous animal origin, remnant of ingested food, or due to the presence of chlorophyllcontaining microorganisms? Siebold (1849) had already stated that the greenish bubbles and grains in Hydra, Turbellaria and some infusoria "are likely closely related to chlorophyll, if not identical", but it was only later that chemical and spectroscopical characterization confirmed the presence of chlorophyll in these animals (reviewed in Buchner 1953). In addition to the general interest in green animals, the British biologist Thomas Huxley initiated another line of research, when he made a rather unremarkable observation about the occurrence of "spherical bright yellow cells" in the colonial radiolarian Thallasicolla while on board the H.M.S. Rattlesnake (Huxley 1851). Things became particularly interesting when Leon Cienkowski reported that these yellow cells continued to grow and divide even after the degradation of the radiolarian colony. Although Cienkowski did not explicitly state their independent nature, he did pose a fundamental question: do the yellow cells really have to be regarded as an essential part of the radiolarian body? (Cienkowski 1871). Surprisingly, the obscure nature of both green and yellow cells and their relationship with both marine and freshwater organisms was more or less resolved within a 7-year period between 1876 and 1883, thanks to a series of independent experiments and observations mainly put forward by Géza Entz, Richard and Oscar Hertwig, Patrick Geddes, and Karl Brandt.

Karl Brandt presented his findings in two presentations in 1881, the first to the Berlin Physiological Society on the 11th of November and the second to the Berlin Society of Friends of Natural Science on the 15th of November. His presentation entitled "Ueber das Zusammenleben von Thieren und Algen" (Concerning the cohabitation of animals and algae) was subsequently published three times in near-identical form by the transactions of both societies (Brandt 1881a, b), and in the journal Botanische Zeitung (Brandt 1882a), edited by Anton 
de Bary and Leopold Just at that time. Furthermore, a fourth, shorter version, summarizing the main findings and essential conclusions, was published with the footnote 'Excerpt of a presentation given to the Physiological Society of Berlin' (Brandt 1881c; complete English translation provided in supplements). Despite its brevity, Brandt's presentation provided a number of major findings on the photosynthetic and self-sufficient nature of these green and yellow cells. Starting from the fundamental question about the nature of chlorophyll in animals, his talk illustrated the morphological characteristics that designated these bodies as unicellular algae, established the first taxonomic designation of Zoochlorella sp. and Zooxanthella sp., and demonstrated their physiological independence and essential capability of re-infecting conspecific hosts. Brandt concluded his presentation with remarks on the specific nutritional nature of the algae-host association and how the functional roles of both partners in this symbiosis compares to other algae-related symbiotic systems known at that time. The four published versions of his presentation (Brandt 1881a, b, c, 1882a) are not completely identical. While the content is similar, the last paragraph differs in two of them (Brandt 1881b, c). In these versions, Brandt explicitly introduces the term "Phytozoe", accompanied by a footnote stating that this term "may provisionally designate animals with green or yellow algae" (cf. Supplements). Peculiarly, Brandt (1881c) is the only version that also contains a statement on the cellulose nature of the outer cell envelope of some green cells (passage highlighted in Supplements), a detail that Brandt failed to address in his presentation, despite explicitly introducing the question in his initial remarks. A short item in the Popular Science Monthly magazine (today Popular Science) entitled "A partnership of animal and plant life" appears to be the only English writing on the subject matter (Brandt 1882b). Despite its publication in German, Brandt's presentation is still considered one of the landmark publications of that time and continues to be cited to the present day.

Brandt's final conclusion on the microalgal nature of green and yellow cells was consistent with many other observations in marine organisms. Even though Brandt used the German word "Zusammenleben" (living together/cohabitation) in his title, he explicitly mentions the term symbiosis at the end of his text and chose it as title in a later publication (Brandt 1883a). Considering the year of his presentation, the term symbiosis was brand-new to the field, as it had just been introduced by Heinrich Anton de Bary (de Bary 1879), in an expansion of Albert Bernhard Frank's term "Symbiotismus" (Frank 1877). De Bary's definition of symbiosis did not define the specific quality of the relationship between the associated partners, but rather integrates symbiosis within a spectrum of relationships (such as mutualisms, commensalisms, parasitisms etc.). Largely unnoticed, Géza Entz had already stated many of Brandt's later conclusions in an earlier presentation given on the second conference of the Kolozsvarian Association of Medical-natural Scientists in Kolozsvar (today Cluj-Napoca, Romania) on the 25th of February 1876. Given in Hungarian at that time, it was only published in German later (Entz 1881). Entz also discovered that the green cells in infusoria (which he called "pseudo chlorophyll bodies") do not belong to a single algal group, as Brandt had suggested with the genus Zoochlorella, but actually represent different algal groups that occur within a similar developmental state when found in association with the animal (Entz 1881, 1882). Also prior to Brandt's findings, the Hertwig brothers had noted the presence of cellulose in the outer envelope of yellow cells of sea anemones and suggested that these cells are "probably basic unicellular algae" (Hertwig and Hertwig 1879). Karl Brandt and Patrick Geddes though widely confirmed the presence of cellulose in yellow cells from radiolarians (Brandt 1882c), sea anemones, the pelagic siphonophore Vellela sp., and the jellyfish Cassiopeia sp. (Geddes 1882b). The experiments conducted by Geddes are of particular significance, since they demonstrated that the cells were able to actively photosynthesise within these animals; observations that were confirmed by measuring the light-dependent concentration of oxygen in bubbles released by the siphonophore Vellela sp., and the green planarian Convoluta schultzii (today Symsagittifera schultzei) (Geddes 1882a, b). Brandt's further work culminated in two extensive publications, both bearing the same title: "Über die morphologische and physiologische Bedeutung des Chlorophylls bei Tieren" (Concerning the morphological and physiological importance of chlorophyll in animals; (Brandt 1882d, 1883b). The latter, an extensive 100-page publication (Brandt 1883b), includes his experimental work at the Stazione Zoologica Anton Dohrn in Naples, Italy and provides an exhaustive synthesis on the matter of green and yellow symbionts. Both publications also contained detailed illustrations of green and yellow cells from a range of hosts, depicting them ex and in hospite, in their natural state, as well as after chemical treatment (Figs. 1, 2).

\section{Translation of Brandt (1881a)}

The following text is a direct translation of Brandt's presentation from 11 November 1881 as recorded in the transactions of the Berlin Physiological Society and published in the Archiv für Anatomie und Physiologie - Physiologische Abtheilung (Brandt 1881a). Furthermore, I have provided another translation of a different, shorter version as published in the journal Biologisches Centralblatt (Brandt 1881c) as Supplement. Text segments that were highlighted in the original document by wider letter-spacing appear bold in the following translation. 


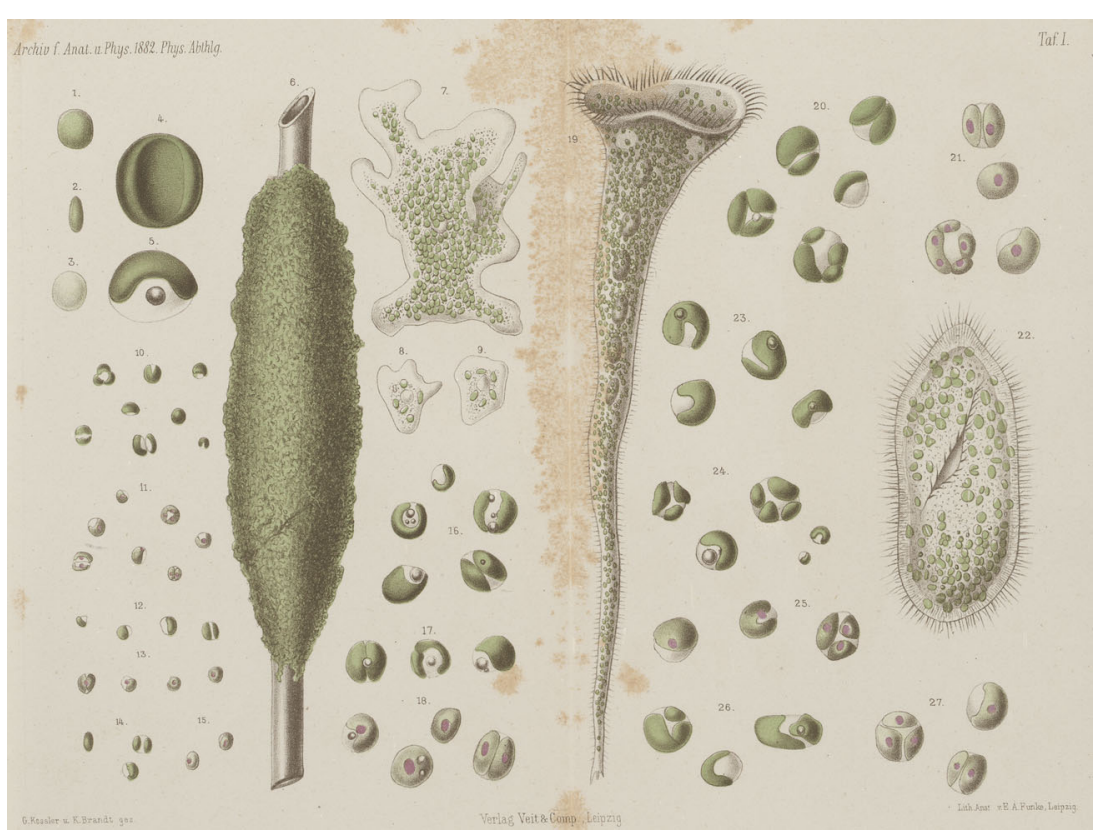

Fig. 1 Illustration of green cells found in animals (from Brandt 1882d). 1-3 Chlorophyll bodies of Lemna. Live within cell. 1600× magnification. 1 Top view, 2 Side view, 3 After treatment with alcohol and hematoxylin. (nucleus not present). 4-5 Schematic of green bodies (particularly from Hydra). 4 Top view of chlorophyll body. 5 Side view of green body with starch grain below. 6 Spongilla, natural size. 7-9 Amoeboid cell of Spongilla. 10-16 and 20-27 Isolated green bodies. $1600 \times$ magnification. 10 Green bodies of Spongilla. 11 Green bodies of Spongilla, treated with hematoxylin. 12 Green bodies of planarian. 13 Green bodies of planarian, treated with hemotoxylin. 14 Green bodies isolated from intestinal wall of Aeolosoma. 15 Green bodies isolated from intestinal wall of Aeolosoma, treated with hematoxylin. 16 Green bodies from Hydra, occasionally with starch grain. 17 Green bodies from Hydra three weeks after isolation. 18 Green bodies from Hydra, treated with hematoxylin. 19 Stentor polymorphus with green bodies. $200 \times$ magnification. 20 Green bodies of Stentor polymorphus. 21 Green bodies of Stentor polymorphus, treated with hematoxylin. 22 Paramecium aurelia with green bodies. $500 \times$ magnification. 23 Green bodies of Paramecium aurelia. 24 Green bodies of Paramecium aurelia, four weeks after isolation. 25 Green bodies of Paramecium aurelia, treated with hematoxylin. 26 Green bodies of Vaginicola crystallina. 27 Green bodies of Vaginicola crystallina, treated with hematoxylin
Addendum to session from 11 November 1881

Herr K. Brandt gives a presentation: Concerning the cohabitation of animals and algae.

Chlorophyll, the green pigment that appears in all plants with the exception of fungi and possesses such an important role does also, as is well known, occur in the animal kingdom. Chlorophyll has for example been documented in certain rhizopods (monothalamians, heliozoans and amoeba), in ciliates (Paramecium, Stentor, vorticellae), in freshwater sponges (Spongilla) and polyps (Hydra), and a number of marine and freshwater turbellarians (Vortex). In all of these animals chlorophyll occurs in the form of distinctly delimited round or oval bodies, quite similar to its appearance in plants.

Concerning the existence of chlorophyll bodies in animals, three opposing views have been developed.

1) Some believe that these green bodies in animals are true chlorophyll bodies that morphologically and physiologically correspond to plant chlorophyll bodies.
2) Others hold the view that the supposed chlorophyll bodies are not created by the animal itself, but should rather be regarded as parasites.

3) And others hold the opinion that - at least in protozoa the green mass is nothing else than ingested plant parts, intended for digestion.

Which of these three opinions is correct has to my knowledge not yet been decided by means of direct investigation. In his publication "Die natürlichen Existenzbedingungen der Thiere" (1880. I. pp. 86-93), which is rich of stimulating thoughts, Semper provides a critical overview of the available information and comes to the conclusion that these green bodies have to be either regarded as endogenous animal products or as housemates (commensals). Of these two views, the latter appears to be more likely to him.

\subsection{Results of my own studies}

First, a morphological investigation involving microchemical reactions is needed in order to provide an answer to this question. In particular, answering three questions was of importance: 


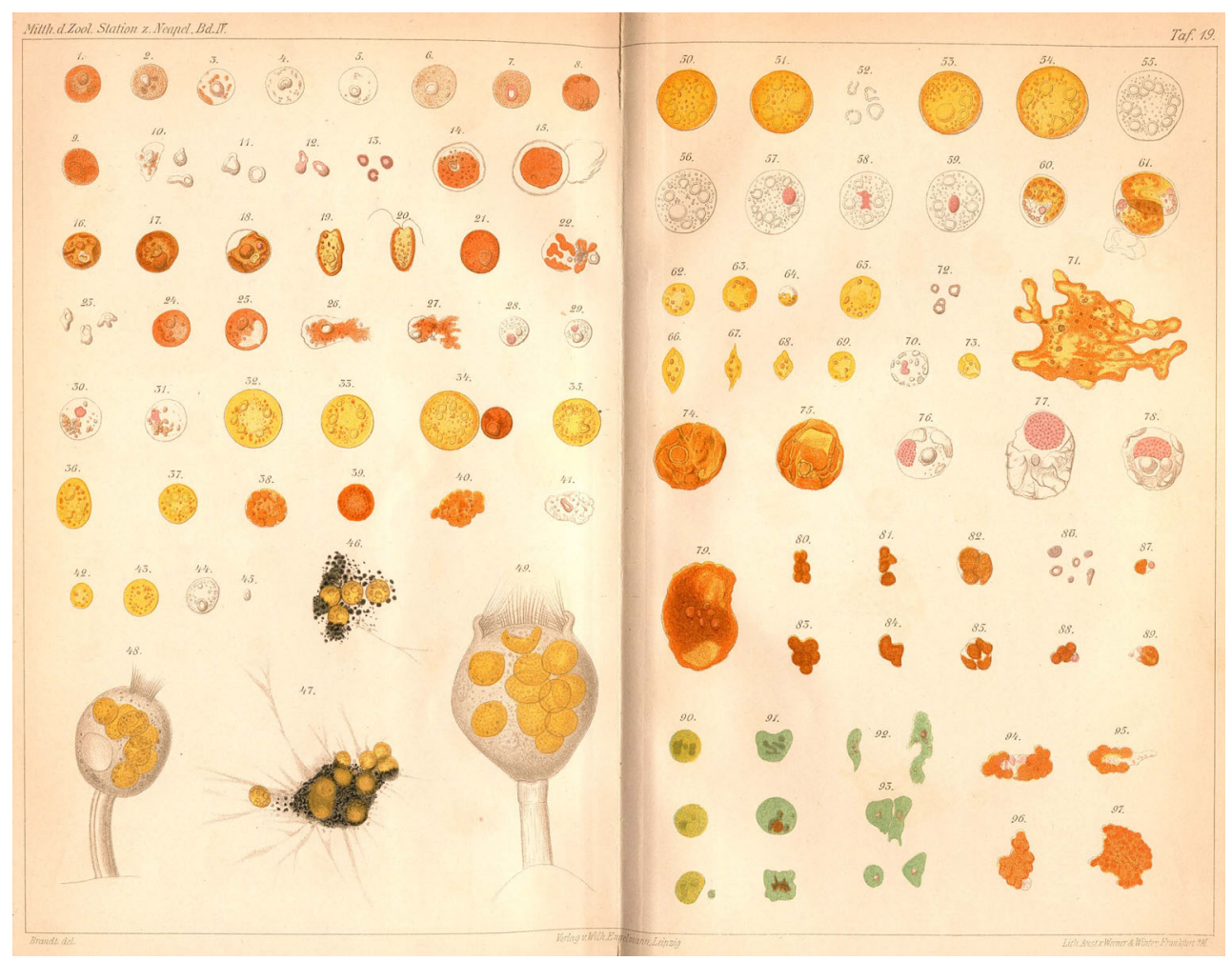

1) Do these green bodies only consist of basic substance and chlorophyll, like true chlorophyll bodies, or do they contain also hyaline, clear protoplasm?

2) Do they contain a nucleus or not?

3) Are they surrounded by a cellulose membrane or not?

Furthermore, it was necessary to determine whether they are physiologically independent or not. In this context, the following points were of particular importance:

1) Do these green bodies survive the death of the animals with whom they live or do they die with them?

2) Is it possible to use a piece of a chlorophyll-containing animal to infect another chlorophyll-free animal?

Morphological studies were performed on Hydra, Spongilla, one freshwater planaria, and a number of infusoria (Stentor, Paramecium, Stylonychia, various vorticellae etc.), by isolating the green bodies from these animals through squeezing and inspecting them under a strong magnification. Frequent investigations on different specimen revealed completely consistent results with regard to the structure of these green bodies:

The green bodies are not homogenously and completely green, but consistently contain hyaline protoplasm next to the green mass. Thus, every green body should not be regarded as chlorophyll body, but as a mass of protoplasm that contains a chlorophyll body. The usually trough-shaped chlorophyll body possesses a strong refractive ability and contains, based on a spectroscopical study of an alcoholic Spongilla extract, true chlorophyll (Fig. 3). Through the application of hematoxylin, it was possible to clearly demonstrate the presence of a nucleus in all green bodies. Either the green bodies were killed by applying chromic acid $(0.2 \%)$ or osmium tetroxide, stripped of chlorophyll with alcohol, and treated with hematoxylin - or they were live-stained with hematoxylin and then treated with alcohol to clean them of their green colour. The result was always the same. In all cases, a violet grain was distinguishable in the hyaline part of the green body. In cases where more than one grain was present in a green body, it was always possible to demonstrate the presence of a number of chlorophyll bodies as well. Cases with 2 6 grains and matching amounts of chlorophyll bodies have to be likely interpreted as division states.

These corroborated findings prove that the apparent chlorophyll bodies of animals are morphologically independent unicellular organisms. Since no algae genus has yet been described to whom these "green bodies" could be assigned, a specific name has to be ascribed.

- Zoochlorella nov. gen. Green body of lower animals in the groups of protozoans, sponges, hydrozoans, and turbellarians.

- Zoochlorella Conductrix mihi. Lives in Hydra. Diameter 3-6 $\mu \mathrm{m}$. The form occurring in ciliates is at least identical with it. 
Fig. 2 Illustration of yellow and green cells found in animals (from Brandt 1883b). All figures are depicted as $1000 \times$ magnification (except 46-49, 90-93). - The yellow cells are always displayed as they appear to the observer when the microscope is adjusted to the equatorial plane. a $1-$ 13 Yellow cells from Anthea cereus [Anemonia sulcata]. 1 After death. 2 Almost completely discoloured after $2 \mathrm{~h}$ of treatment with alcohol. 3 After alcohol treatment and Lugol's solution with subsequent iodine removal using acetic acid. Only the starch grain is stained purple. $4-6$ After $3 \mathrm{~h}$ of alcohol treatment and $1 \mathrm{~h}$ of acetic acid ( $1 \%) .7 \mathrm{~A}$ single yellow cell that was treated the same way as the previous ones followed by incubation in Lugol's solution for 30 min. $8-10$ Yellow cells after $7 \mathrm{~h}$ of treatment with sodium hydroxide $(0.5 \%)$. Their colour has changed only slightly. In many cases, there was leakage of coloured plasma, retaining only the starch grain and other grains in the folded membrane (Fig. 10). 11 Isolated hollow starch grains. 12 Isolated starch grains after treatment with Lugol's solution. The Anthea [Anemonia] animals, whose yellow cells were used, were only exposed to low light. 13 Isolated starch grains after treatment with Lugol's solution. The Anthea [Anemonia] animals were exposed to direct sunlight for 3 h. 14-19 Yellow cells from Aiptasia diaphana. 14, 15 Three months after isolation from Aiptasia. The membrane has thickened. Fig. 15: Shed hull next to a yellow cell. 16-19 Isolated yellow cells after death. The yellow cell in Fig. 19 has the shape of a swarming spore of the phaeosporeae(?). 20 Swarming spore of phaeosporeae(?). Very similar to the yellow cell from Aiptasia depicted in Fig. 19. 21-23 Yellow cells from Cladocora caespitosa. 21 Intact. 22 Squashed. 23 Isolated starch grains. 24-26 Yellow cells from Cassiopeia borbonica [Cotylorhiza tuberculate]. 24, 25 After death. 26 Squashed. 27 Yellow cells from from Heliactis bellis [Cereus pedunculatus], squashed. 28, 29 Yellow cells from Anthea cereus [Anemonia sulcata] after treatment with chromic acid $(0.5 \%)$, Magdala red [Azotrinaphthyldiamine] and alcohol. Balsam preparation. Nucleus. 30, 31 Yellow cells from from Cereactis aurantiaca [Condylactis aurantiaca]. The hollow starch grain was not visible. Balsam preparation. Nucleus. 30 After treatment with chromic acid, Magdala red [Azotrinaphthyldiamine], alcohol. 31 After treatment with chromic acid, alcohol, Kleinenberg's alcohol. Hematoxylin solution, alcohol. 32-34 Yellow cells from Velella [Vellela vellela], after death. 32,33 The yellow cells that commonly occur in Velella. 34 Two different kinds of yellow cells from the same Vellela individual. 35 Yellow cells from Vorticella n. sp. (living on Aglaophenia), after death. 36, 37 Yellow cells from Globigerina echinoides [Coscinosphaera ciliosa], after death. 38-41 Amoeboid

- Zoochlorella parasitica mihi. Lives in freshwater sponges. Diameter $1.5-3 \mu \mathrm{m}$. Probably identical to the form occurring in freshwater planarians.

At the same time, I permit myself to assign a corresponding genus name to the yellow cells that live under similar circumstances and whose morphological and physiological independence from the animals with whom they live has been demonstrated by studies of Cienkowski, Hertwig and myself:

- Zooxanthella nov. gen. Yellow cells of radiolarians, certain hydrozoans, and actinians

- Zooxanthella nutricula mihi. Yellow cells of Collozoum inerme. Yellow cells of polycyttarians and many monocyttarians are probably identical with this species.

Besides the morphological independence of zoochlorellae, their physiological independence remained to be proven. yellow cells from Paralcyonium elegans [Paralcyonium spinulosum]. 38-40 After death. 41 Destained with alcohol and subsequently treated with Lugol's solution. 42-45 Yellow cells from Hircinia variabilis [Ircinia variabilis]. 42, 43 After death. 44 Destained with alcohol. 45 Isolated starch grain. 46, 47 Extracapsular "Sarkode" [protoplasm] from Thalassicolla nucleata with dense pigment grains and yellow cells. 48, 49 Vorticella $\mathrm{n} \mathrm{sp}$. (living on Aglaophenia) with yellow cells. Peristome always more or less retracted. Magnification 400. b 50-57 Yellow cells from Sphaerozoidae. 50, 51 Yellow cells from Collozoum inerme, after death. 52 Isolated starch grains of these yellow cells. 53, 54 Yellow cells from Sphaerozoum neapolitanum, after death. 55, 56 The same cells after $1 \mathrm{~h}$ incubation with alcohol. 57 Yellow cells from $S$. neapolitanum after treatment with alcohol and staining with Magdala red [Azotrinaphthyldiamine]. Nucleus. 58, 59 Yellow cells from Myxobrachia rhopalum (=Thallasicolla sanguinolenta). Balsam preparation. Nucleus. After treatment with chromic acid, alcohol, Kleinenberg's hematoxylin, alcohol. 60, 61 Free-living yellow cells from the seawater (upwelling). 62-73 Yellow cells from Acanthometrida [Arthracanthida]. 62-64 Yellow cells from Acanthometra elastica. 65 Yellow cells from Amphilonche belenoides. 66-69 Cells from Acanthometra tetracopa, some of them spindle-shaped. 70 Yellow cells from Acanthometra elastica after treatment with osmium, Beale's carmin and alcohol. Balsam preparation. Nucleus. 71 Yellow cells from Acanthometra tetracopa. 72 Starch grains, which were made visible in this yellow cell using diluted ammonia. They were stained with Lugol's solution. 73 Small yellow cells from the same specimen of Acanthometra tetracopa as in figure 71. 74-79 Yellow cells from Convoluta langerhansii [Amphiscolops langerhansii]. 74, 75 fAfter death. 76-78 Yellow cells in histological sections from Convoluta, which were treated with corrosive sublimate (mercuric chloride), picrocarmine, borax, carmine, alcohol, paraffin, creosote, and Canada balsam. Nucleus (appears granulated). 79 After treatment with Lugol's solution. Starch grains are purple. 80-89 Yellow cells from Eunice gigantean. 80-85 After death. 86-89 After treatment with Lugol's solution. Hollow starch grains are stained. 90 93 Green bodies of Elysia. - Magnification 2000. (with Zeiss 1/12 oil immersion objective). 90, 91 Treated with Lugol's solution. (Irregular starch grains deeply stained). 92, 93 Treated with osmium and hematoxylin (nucleus). 94-96 Amoeboid yellow cells from Echinocardium cordatum. After death. 97 Yellow cells from the larvae of Holothuria tubulosa. After death

Green bodies from freshwater sponges and ciliates were isolated through squeezing and cultivated on glass slides. It was demonstrated that isolated zoochlorellae by no means die, but continue to live for days and weeks. When exposed to light, starch grains appear within them - a sign that they have not lost their functionality.

Moreover, infection experiments were conducted. In the course of the experiment it was demonstrated that the aforementioned species of Zoochlorella that were designated based on their size differences are not just morphologically diverse, but also show physiological differences. When providing chlorophyll-free infusoria with isolated green bodies from freshwater sponges, it was demonstrated that although many of them were taken up, they could not successfully be retained and were either digested or expelled. Even infusoria that usually harbour zoochlorellae (the bigger species, however) did not keep them. 
Fig. 3 These illustrations and their legends were embedded in the original text body. 1. Top view of a green body. One can only recognize the trough-shaped chlorophyll body. 2 . Side view of a green body. The less refractive, clear protoplasm shows a starch grain. 3. A green body with 2 chlorophyll bodies. (drawn by G. Kessler).

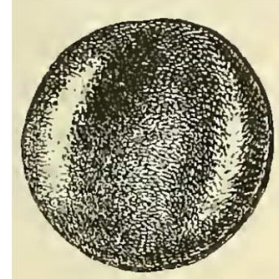

Fig. 1.

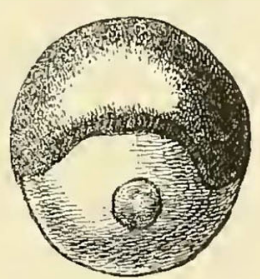

Fig. 2.

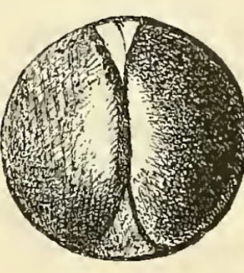

Fig. 3.
On the other hand, it was possible to infect chlorophyll-free infusoria with zoochlorellae from a dead Hydra viridis. A number of ciliates that are usually free of green bodies took up Hydra parasites and kept them over time (Coleps, Paramecium, Stylonychia etc.).

Concluding from the presented data, self-formed chlorophyll is lacking in animals. Chlorophyll does only occur in true plants. When found in animals, its existence is attributed to colonized parasites.

\subsection{General findings}

When I used the term "parasite" in the previous paragraph, it was merely due to brevity and also because these algae appear from a morphological perspective for the moment as parasites of animals. However, they cannot be seen as true parasites in the physiological sense. One should not draw a parallel with parasitic fungi, tapeworms etc., because these extract substances from their host and do not produce, even lesser, release such compounds. Zoochlorellae and zooxanthellae, however, produce organic compounds from water and carbonic acid in the likeness of true plants.

Thus, they are expected not to withdraw organic compounds, but rather deliver them to their host. Indeed, the latter is true as illustrated by the following observations:

1) When closely inspecting the jelly of big colonial radiolarians, I was unable to find foreign material that was in some state of digestion.

Given their considerable body mass, these animals require large amounts of food. Since they are unable to generate organic compounds from water, carbonic acid and ammonia, they can only be kept alive by their yellow cells, which they harbour in considerable densities.

2) Such colonies were best kept alive, when submerged in filtered seawater. Under these conditions, they were completely unable to feed on organic matter like true animals.

3) Freshwater sponges were equally well kept in filtered river water. Even if the water was filtered on a daily basis, they thrived marvellously. Only when placed in a semi- dark room, they died. Sufficient lighting is absolutely necessary.

It is hereby demonstrated that zooxanthellae and zoochlorellae completely sustain their host. As long as these animals contain only few or no green or yellow cells at all, they feed like true animals by ingesting organic substances. As soon as they contain sufficient algae, they feed like true plants, through assimilation of inorganic compounds. They have to feed like animals as soon as limiting light reduces the function of their algae. They die if they do not shift to their original mode of feeding.

Botanical studies have shown two different kinds of algal cohabitation with other plant organisms. Firstly, algae live as "tenants" in other chlorophyll-containing plants. Secondly, algae live in association with fungi, forming the so-called lichens, as highlighted by Schwendener. In the first case, parasitizing algae are generally indifferent towards their host's assimilation mode. Algae, as well as the plants they live in, feed through assimilation of inorganic compounds. In lichens, algae supply the nutrition for their parasitizing fungi. The algae transform inorganic compounds into organic ones and the fungus consumes them.

Similar to this case, yet different, is the association of algae with animals. Generally, the same principles apply in lichens and green and yellow animals: The algae transform inorganic compounds into organic ones and the animal consumes them. However, while we find in lichens that true parasites (fungi) are associated with algae, we see in green and yellow animals a symbiosis of algae with animals that are used to an independent and self-sufficient lifestyle. As soon as their green and yellow algae have colonized and sufficiently grown in density, they give up their independent life and let themselves completely feed by their "parasites". Although capable - they are morphologically equivalent to chlorophyll-free animals - the do not assimilate solid organic substances anymore. The cohabitation of algae and animals is the most peculiar case. From a morphological point of view, the algae are parasites, while from a physiological point of view, the animals are the parasites.

The studies were conducted at the local physiological institute. 


\section{On the matter of Brandt's taxonomy}

Some opposition remained following Brandt's conclusions. Lankester (1882) for example, argued that the "greencoloured corpuscles" of Hydra and Spongilla were more similar to the chloroplasts of plants and should not be regarded as symbiotic algae. However, the cultivation and description of some of Brandt's Zoochlorella sp. as Chlorella vulgaris by Martinus Willem Beijerinck (spelled as Beyerinck in some German publications) certainly ended the debate (Beyerinck 1890). It should however be noted that direct cultivation from Spongilla or Hydra animals was initially not achieved, even though one or two cell divisions were observed provided the cells were kept in contact with animal protoplasm (Beyerinck 1890). Later attempts that included the addition of organic supplements such as glucose improved the cultivation of Chlorella from the freshwater sponge Euspongilla lacustris and the platyhelminth Castrada viridis Volz (Limberger 1918). Recognizing Zooxanthella sp. as independent organism paved the way for the research of Hovasse, Kawaguti, McLaughlin, Zahl, Taylor, and Trench in the twentieth century and led to the successful cultivation, identification, and description of Zooxanthella sp. as dinoflagellates. Unfortunately, Brandt's classification of green and yellow cells in animals as Zoochlorella sp. and Zooxanthella sp. in the 1880's was also the starting point for a hundred years of extensive renaming and reclassification, especially in the genus Zooxanthella, leading in some cases to multiple synonyms for the same species (reviewed in Reisser 1984; Blank and Trench 1986; Stat et al. 2012). Brandt's justified the creation of both genera with the fact that these algae did not resemble any of the described algal groups at that time, but admits later that this was a mistake given the findings of Entz (Entz 1881, 1882) for zoochlorellae and that the genus name Zoochlorella should be retracted (Brandt 1883b; pp. 193, 245).

Zooxanthella chattoni (Hovasse 1924) and Z. nutricula (Brandt 1881a) are the only formally recognized species of the genus Zooxanthella, according to algaebase.org (Guiry and Guiry 2016). The colloquial term "zooxanthellae" on the other hand has been defined as "endosymbiotic algae belonging to various taxa of chromophyte algae" by the same source and can be found throughout the literature. Thus, ironically, zooxanthellae do not necessarily belong to the genus Zooxanthella. In fact, multiple genera such as Amphidinium (Jørgensen et al. 2004), Gymnodinium (Gast and Caron 1996), Symbiodinium (Freudenthal 1962; LaJeunesse 2001), and Brandtodinium (Probert et al. 2014) that associate with a range of radiolarian, anthozoan, foraminiferan, and protist hosts are all zooxanthellae, but some of them have only a distant phylogenetic relationship with Zooxanthella (Gottschling and McLean 2013). Modern molecular techniques have illustrated how phylogenetically divergent members of zooxanthellae and zoochlorellae are to each other in each group. In the case of the coral symbiont Symbiodinium sp. (Freudenthal 1962), biomolecular and phylogenetic work has now established a large degree of intrageneric diversity that can be larger than the diversity observed between different genera in higher plants (LaJeunesse 2001; Krueger et al. 2015). Considering the achieved taxonomic resolution through the use of modern molecular genetic tools, the designation "zooxanthellae" is clearly outdated and should be discouraged in scientific publications (see also Blank and Trench 1986; Gottschling and McLean 2013). Similar concerns were raised about the usefulness of the term zoochlorellae, since its arbitrary assignment to many green cells that live with heterotrophic organisms can cause uncertainties about the true algal identity, leading to the suggestion to treat it as a nomen ambiguum (reviewed in Reisser 1984).

While Karl Brandt was neither the first nor the only one to recognize the independence and symbiotic nature of green and yellow cells in animal hosts, his experimental work and publications certainly helped to ultimately convince the broader scientific community and thus create a new frontier of research. Today, symbiosis is recognized as a fundamental and widespread phenomenon. Studying the physiological and ecological features of these symbiotic systems remains one of the most dynamic and fascinating topics in biology.

Acknowledgments The direct online access to scanned original documents was made possible through the efforts and dedication of the people behind the Biodiversity Heritage Library (http://www.biodiversitylibrary. org/). Thanks also go to Prof. Christian Voolstra, Prof. Maoz Fine, and Dr. Emma Gibbin for helpful comments on the translation. High resolution scans of figures were kindly provided by the Zentralbibliothek Zürich (Fig. 1) and Prof. Andrew Baker (Fig. 2).

\section{Compliance with ethical standards}

Conflict of interest The author declares no conflict of interest.

\section{References}

Beyerinck, MW (1890) Culturversuche mit Zoochlorellen, Lichenengonidien und anderen niederen Algen. Botanische Zeitung 45:725-785

Blank RJ, Trench RK (1986) Nomenclature of endosymbiotic dinoflagellates. Taxon 35:286-294

Brandt K (1881a) Ueber das Zusammenleben von Thieren und Algen. Verhandlungen der physiologischen Gesellschaft zu Berlin 1880 1881 - published in Archiv für Anatomie und Physiologie Physiologische Abtheilung. Physiologische Gesellschaft zu Berlin/ Berlin Physiological Society, Berlin 570-574

Brandt K (1881b) Ueber das Zusammenleben von Thieren und Algen. Sitzungs-Berichte der Gesellschaft Naturforschender Freunde zu Berlin. Gesellschaft Naturforschender Freunde (GNF)/Berlin Society of Friends of Natural Science, Berlin 140-146

Brandt K (1881c) Ueber das Zusammenleben von Algen und Tieren. Biologisches Centralblatt 1:524-527 
Brandt K (1882a) Ueber das Zusammenleben von Thieren und Algen. Botanische Zeitung 40:248-254

Brandt K (1882b) A partnership of animal and plant life. The Popular Science Monthly 21:835-836

Brandt K (1882c) Untersuchungen an Radiolarien. Monatsberichte der Königlich Preussischen Akademie der Wissenschaften zu Berlin April 1881:388-404

Brandt K (1882d) Über die morphologische und physiologische Bedeutung des Chlorophylls bei Thieren. Archiv für Anatomie und Physiologie-Physiologische Abtheilung:125-151

Brandt K (1883a) Ueber Symbiose von Algen und Thieren. Archiv für Anatomie und Physiologie - Physiologische Abtheilung:445-454

Brandt K (1883b) Über die morphologische und physiologische Bedeutung des Chlorophylls bei Thieren. 2. Artikel. Mittheilungen aus der zoologischen Station zu Neapel 4:191-302

Buchner P (1953) Endosymbiose der Tiere mit pflanzlichen Mikroorganismen. Springer, Basel

Cienkowski L (1871) Ueber Schwärmerbildung bei Radiolarien. Arch Mikrosk Anat 7:372-381

de Bary A (1879) Ueber Symbiose. Tageblatt der 51 Versammlung deutscher Naturforscher und Aerzte in Cassel:121-126

Entz G (1881) Ueber die Natur der "Chlorophyllkörperchen" niederer Thiere. Biologischen Centralblatt 1:646-650

Entz G (1882) Das Konsortialverhältniss von Algen und Tieren. Biologisches Centralblatt 2:451-464

Frank AB (1877) Über die biologischen Verhältnisse des Thallus einiger Krustenflechten. Beiträge zur Biologie der Pflanzen 2:123-200

Freudenthal, HD (1962) Symbiodinium gen. nov. and Symbiodinium microadriaticum sp. nov., a Zooxanthella : Taxonomy, life cycle, and morphology. J Protozool 9:45-52

Gast RJ, Caron DA (1996) Molecular phylogeny of symbiotic dinoflagellates from planktonic Foraminifera and Radiolaria. Mol Biol Evol 13:1192-1197

Geddes P (1882a) On the Nature and Functions of the "Yellow Cells" of Radiolarians and Cœlenterates. Proceedings of the Royal Society of Edinburgh 11:377-396

Geddes P (1882b) Further researches on animals containing chlorophyll. Nature 25:303-305

Gottschling M, McLean TI (2013) New home for tiny symbionts: Dinophytes determined as Zooxanthella are Peridiniales and distantly related to Symbiodinium. Mol Phylogenet Evol 67:217-222
Guiry MD, Guiry GM (2016) AlgaeBase. World-wide electronic publication, National University of Ireland, Galway. Retrieved from http://www.algaebaseorg on 13 April 2016

Hertwig O, Hertwig R (1879) Die Actinie Anatomisch und Histologisch. Fischer Verlag, Jena

Hovasse R (1924) "Zooxanthella chattonii" (Endodinium chattonii). Etude complémentaire. Bulletin biologique de la France et de la Belgique 58:38-48

Huxley TH (1851) Upon Thalassicolla, a new zoophyte. Zoological notes and observations made on board HMS Rattlesnake. Ann Mag Nat Hist: Series 2 8:433-442

Jørgensen MF, Murray S, Daugbjerg N (2004) Amphidinium revisited. I. Redefinition of Amphidinium (Dinophyceae) based on cladistic and molecular phylogenetic analyses. J Phycol 40:351-365

Krueger T, Fisher PL, Becker S, Pontasch S, Dove S, Hoegh-Guldberg O, Leggat W, Davy SK (2015) Transcriptomic characterization of the enzymatic antioxidants FeSOD, MnSOD, APX and KatG in the dinoflagellate genus Symbiodinium. BMC Evol Biol 15:48

LaJeunesse TC (2001) Investigating the biodiversity, ecology and phylogeny of endosymbiotic dinoflagellates in the genus Symbiodinium using the ITS region: In search of a "species" level marker. J Phycol $37: 866-880$

Lankester ER (1882) On the chlorophyll-corpuscles and amyloid deposits of Spongilla and Hydra. J Cell Sci 22:229-254

Limberger A (1918) Über die Reinkultur der Zoochlorella aus Euspongilla lacastris und Castrada viridis Volz Sitzungsberichte der Kaiserlichen Akademie der Wissenschaften in Wien. Kaiserliche Akademie der Wissenschaften, Wien, Austria 395-412

Probert I, Siano R, Poirier C, Decelle J, Biard T, Tuji A, Suzuki N, Not F (2014) Brandtodinium gen. nov. and B. nutricula comb. nov. (Dinophyceae), a dinoflagellate commonly found in symbiosis with polycystine radiolarians. J Phycol 50:388-399

Reisser W (1984) The taxonomy of green algae endosymbiotic in ciliates and a sponge. Br Phycol J 19:309-318

Siebold CTv (1849) Über einzellige Pflanzen und Tiere. Zeitschrift fur wissenschaftliche Zoologie 1:270-294

Stat M, Baker AC, Bourne DG, Correa AM, Forsman Z, Huggett MJ, Pochon X, Skillings D, Toonen RJ, van Oppen MJ (2012) Molecular Delineation of Species in the Coral Holobiont. Adv Mar Biol 63:1-65 